\title{
The Social Impact of CSR Campaigns Among a Higher Education Institution From Romania
}

\author{
Lecturer Veronica loana ILIEŞ, PhD \\ Department of Communication, Public Relations and Advertising \\ Faculty of Political, Administrative and Communication Sciences, \\ Babeş-Bolyai University, Cluj-Napoca \\ E-mail: ilies@fspac.ro
}

\section{Assistant Professor Paul-Alexandru FĂRCAŞ, PhD \\ Department of Communication, Public Relations and Advertising Faculty of Political, Administrative and Communication Sciences, Babeş-Bolyai University, Cluj-Napoca \\ E-mail: farcas@fspac.ro}

\begin{abstract}
Social responsibility campaigns implemented within higher education institutions from Romania are at an early stage, but with a growing interest in this field. These programs are built with the desire to convince and help the academic community to invest in the development of students, professors and auxiliary staff and to make a contribution to the development of local communities. Even if social impact assessment of this kind of projects is a complex process, by involving several beneficiaries and by producing visible results, a University may create serious premises in continuing and developing such programs in the academic sphere. An important aspect on launching social projects is tied to a clear identification of the real needs of the beneficiaries, the social sustainability of the actions after the program is finished and establishing an effective budget. Such projects may be developed not only in business area, but in educational institutions as well. The so called university social responsibility is based on the identification of social issues that may represent good opportunities to get involved in the community. To better
\end{abstract}




\section{References}

1. Christensen, L.J., Peirce, E., Hartman, L.P., Hoffman, W.M., Carrier, J. (2007). Ethics, CSR, and Sustainability Education in the Financial Times Top 50 Global Business Schools: Baseline Data and Future Research Directions, Journal of Business Ethics, Vol. 73, 347-368.

2. Dahan, G.S., Senol, I. (2012). Corporate Social Responsibility in Higher Education Institutions: Istanbul Bilgi University Case. American International Journal of Contemporary Research, Vol. 2, No. 3, March, 95-103.

3. Didier, C., Huet, R. (2008). Corporate social responsibility in engineering education. A French survey, European Journal of Engineering Education, 33:2, 169-177, doi: 10.1080/03043790801976472.

4. Etzokwitz, H. (2002). The triple helix Model of University-Industry-Government Implications for Policy and Evaluation, Science Policy Institute. Working paper 2002-11. Institutet för studier av utbildning och forskning, ISSN 1650-3821, 1-18.

5. Fernández, J., L., Bajo-Sanjuán, A. (2010). The Presence of Business Ethics and CSR in Higher Education Curricula for Executives: The Case of Spain, Journal of Business Ethics Education, Vol. 7, 25-38.

6. Giuffre, L., Ratto, S.E. (2014). A new paradigme in higher education: University Social Responsability (USR). Journal of Education \& Human Development, Vol. 3, No. 1, 231-238. ISSN: 2334-296X (Print), 2334-2978 (Online).

7. Goosen, R. (2009). Universities and Corporate Social Responsibility: A Competitive Advantage? Retrieved from http://www.avantagepartners.com/content/universi ties-and-corporate-social-responsibility-competitive-advantage, accessed 14 February 2012

8. Gumport, P.J. (2000). Academic Restructuring: Organizational Change and International Imperatives. Higher Education 39, 67-91.

9. Hasrouni, L. (2012). Cultivating Values. How business schools can plant the seeds of change, Responsile Business, July-September, 56-68.

10. Inzelt, A., Laredo, P., Sanchez, P., Marian, M., Vigano, F., Carayol, N. (2006). Third Mission, Methodological Guide, Strategic management of University research activities, Observatory of the European University, PRIME -Network of Excellence funded by the European Commission, FP6 - Citizens and Governance in a knowledge-based society EC Contract Number: CITI-CT-2003-506596, Lugano, 117-152.

11. Jimenez de la Jara, M. (2007). The Socially responsible university: a way of being, Global University Network for Innovation, Retrieved from www.guninetwork.org/ articles/socially-responsible-university-way-being, accessed on January 7, 2017. 
12. Kleinrichert, D., Albert, M., Eng, J.P. (2011). The Role of Corporate Values on Business Students' Attitudes: A Comparison of Undergraduates and MBAs, The Business Review, Vol. 17, No. 1, 53-59.

13. Kolodinsky, R.W., Madden, T.M., Zisk, D.S., Henkel, E.T. (2010). Attitudes about Corporate Social Responsibility: Business Student Predictors, Journal of Business Ethics, Vol. 91, No. 2, 167-181.

14. Leitão, J., Silva, M.J. (2007). CSR and Social Marketing: What is the desired role for Universities in fostering Public Policies? University of Beira Interior, MPRA Paper No. 2954.

15. Luthar, H., Karri, R. (2005). Exposure to Ethics Education and the Perception of Linkage between Organizational Ethical Behavior and Business Outcomes, Journal of Business Ethics, Vol. 61, No. 4, 353-368.

16. Mahoney, J. (1990). Teaching Business Ethics in UK, Europe and the U.S.A: A comparative Study, London: Athlone Press.

17. McKenna, R.J. (1995). Business Ethics Education: Should we? Can we? Journal of Australian and New Zealand Academy of Management, Vol. 1, No. 2, 44-63.

18. Moon, J., Orlitzky, M. (2011). Corporate Social Responsibility and Sustainability Education: A Trans-Atlantic Comparison, Journal of Management E Organization, Vol. 17, No. 5, 583-603.

19. Neubaum, D., Pagell, M., Drexler, J., McKee-Ryan, F., Larson, E. (2009). Business Education and its Relationship to Student Personal Moral Philosophies and Attitudes toward Profits: An Empirical Response to Critics, Academy of Management Learning E Education, Vol. 8, No.1, 9-24.

20. Peric, J. (2012). Development of Universities'Social Responsibility through Academic service learning programs. J.J. Strossmayer University in Osijek. Faculty of Economics in Osijek. Retrieved from http://www.cepor.hr/App\%207-Social\%20res ponsible\%20universities_full\%20paper_Julia\%20Peric.pdf, accessed on on January 7, 2017.

21. Setó-Pamies, D., Domingo-Vernis, M., Rabassa-Figueras, N. (2011). Corporate Social Responsibility in Management Education: Current Status in Spanish Universities, Journal of Management \& Organization, Vol. 17, No. 5, 604-620.

22. Sobczak, A., Debucquet, G., Havard, C. (2006). The Impact of Higher Education on Students' and Young Managers' Perception of Companies and CSR: An Exploratory Analysis, Corporate Governance, Vol.6, No. 5, 463-474.

23. Vallaeys, F. (2007). Responsabilidad Social Universitaria. AUSJAL Meeting, Caracas, Venezuela.

24. Vanasupa, L., Slivovsky, L., Chen, K.C. (2005). Global challenges as inspiration: A classroom strategy to foster social responsibility. Paper presented at the 2005 conference, Ethics and Social Responsibility in Engineering and Technology, Linking Workplace Ethics and Education, Los Angeles, CA, USA, Retrieved from http:// digitalcommons.calpoly.edu/cgi/viewcontent.cgi?article=1006\&context=mate_fac, accessed on January 7, 2017. 
25. Vasilescu, R., Barnda, C., Epure, M., Baicu, C. (2010). Developing university social responsability: A model for the challenges of the new civil society. Social and Behavioral Sciences, 2, 4177-4182. doi: 10.1016/j.sbspro.2010.03.660.

26. Vazquez, J. L., Lanero, A., Lisandro, O. (2013). Corporate social responsibility and higher education: Uruguay University Students` perception', Economics \& Sociology, Vol. 6, No. 2, 145-157. doi: 10.14254'2071-789X.2013/6-2/13.

27. Wigmore-Alvarez, A., Ruiz-Lozano, M. (2012). University Social Responsibility (USR) in the Global Context: An Overview of Literature. Business \& Professional Ethics Journal, 31:3-4, 475-498. doi: 10.5840/bpej201231/424.

28. Wu, Y.J., Huang, S., Kuo, L., Wu, W. (2010). Management Education for Sustainability: A Web-Based Content Analysis, Academy of Management Learning \& Education, Vol. 9, No. 3, 520-531.

29. ${ }^{* * *}$ International Meeting on Social Responsibility in Universities. (2013). University of Cádiz. Retrieved from http://rsuniversitaria.org/web/images/stories/__INTERNATIONAL_MEETING_ON_SOCIAL_RESPONSIBILITY_OF_UNIVERSITIES. pdf, accessed on January 7, 2017.

30. ${ }^{* * *}$ European Commission. (2011). A renewed EU strategy 2011-2014 for Corporate Social responsibility. Brusseles, 3-15, Retrieved from http://www.europarl.europa.eu/ meetdocs/2009_2014/documents/com/com_com(2011)0681_/com_com(2011)0681_ en.pdf, accessed on January 7, 2017.

31. ${ }^{* * *}$ European Commission. (2013). How Companies influence our society: citizens` view REPORT. Conducted by TNS Political \& Social at the request of the European Commission, Directorate-General Enterprise and Industry Survey co-ordinated by the European Commission, Directorate-General for Communication (DG COMM "Research and Speechwriting" Unit), Eurobarometer 363, 3-71.

32. ***The Hong Kong Polytechnic University (PolyU). (2014). USR Summit 2014. Retrieved from http://www.usrnetwork.org/about-usrn/background, accessed on January 7, 2017.

33. ${ }^{* * *}$ World Conference on Higher Education. Final Report. (2009). Paris, UNESCO Headquarters, 5 to 8 July, Retrieved from http://unesdoc.unesco.org/images/0018/ 001892/189242e.pdf, accessed on January 7, 2017.

34. ${ }^{* * *}$ Carta UBB http://www.ubbcluj.ro/ro/infoubb/documente_publice/files/Carta_ 2014.pdf.

35. ${ }^{* * *}$ Plan Strategic UBB http://www.ubbcluj.ro/ro/despre/prezentare/files/strategii/ plan_strategic_2012_2015.pdf. 